Eduvest - Journal of Universal Studies

Volume 1 Number 12, December 2021

p- ISSN 2775-3735 e-ISSN 2775-3727

\title{
THE EFFECT OF WOUND CARE WITH PALM SUGAR ON DIABETIC ULCER REPAIRING IN TYPE 2 DIABETES PATIENTS
}

\section{Devi Ratnasari, Eva Daniati, Eti Suliyawati, Zahara Farhan}

STIKes Karsa Husada, Garut, Indonesia

E-mail: nersdevi@gmail.com, evadaniati4@gmail.com, hsuliyawati@gmail.com, zaharafarhan585@gmail.com

\begin{tabular}{|c|c|}
\hline ART & ABSTRACT \\
\hline $\begin{array}{l}\text { Received: } \\
\text { November, 26 } \\
2021 \\
\text { Revised: } \\
\text { December, 17th } \\
2021 \\
\text { Approved: } \\
\text { December, 19th } \\
2021\end{array}$ & $\begin{array}{l}\text { Diabetic ulcers are one of the most common complications } \\
\text { of type } 2 \text { diabetes mellitus. Diabetic ulcers are infected } \\
\text { sores that develop in the lower extremities. Proper } \\
\text { diabetic foot wound care methods will improve wound } \\
\text { healing. One of the efforts to treat the complement to } \\
\text { prevent infection is wound care with palm sugar. Palm } \\
\text { sugar contains antibiotic-like substances such as vitamin } \\
\text { C, riboflavin, vitamin A, and ascorbic acid. Dr. Slamet } \\
\text { Garut's study aims to determine the effectiveness of } \\
\text { wound care with palm sugar media against the repair of } \\
\text { diabetic ulcers in patients with type } 2 \text { diabetes mellitus } \\
\text { after hospitalization in } 2021 \text {. The study used a quasi } \\
\text { experimental research design with one group pretest and } \\
\text { posttest design (Pre-action) and one group of subjects } \\
\text { receiving palm sugar therapy on diabetic ulcer wounds } \\
\text { (Post-action). The researcher used consecutive sampling } \\
\text { techniques, samples that met the inclusion criteria could } \\
\text { have } 8 \text { people. The wounds were treated with palm sugar } \\
\text { for two weeks. The findings revealed that wound care } \\
\text { with palm sugar had an effect on the repair of diabetic } \\
\text { ulcers in patients with type } 2 \text { diabetes mellitus, with a }\end{array}$ \\
\hline
\end{tabular}

Devi Ratnasari, Eva Daniati, Eti Suliyawati, Zahara Farhan (2021).

The Effect of Wound Care with Palm Sugar on Diabetic Ulcer Repairing in Type 2 Diabetes Patients. Journal Eduvest. 1(12):

How to cite:

E-ISSN:

Published by: $\quad$ https://greenpublisher.id/ 


\begin{tabular}{ll}
\hline & $\begin{array}{l}\text { Pvalue }=0.000 . \text { Then it is possible to conclude that } \\
\text { treating wounds with palm sugar affects the improvement } \\
\text { of diabetic ulcers. }\end{array}$ \\
\hline KEYWORDS & $\begin{array}{l}\text { Wound Care, Palm Sugar, Diabetic Ulcer, Diabates Mellitus } \\
\text { Type 2 }\end{array}$ \\
\hline CC (5) (9) & $\begin{array}{l}\text { This work is licensed under a Creative Commons } \\
\text { Attribution-ShareAlike 4.0 International }\end{array}$ \\
\hline
\end{tabular}

\section{INTRODUCTION}

Diabetic ulcers, which occur in the lower extremity and are caused by three factors: peripheral innervation disorders (neuropathy), infections, and impaired blood flow, are one of the most common complications of neuropathy (Christia et al., 2015). The presence of this condition causes wounds to heal more slowly, making them more susceptible to infection, which can lead to tissue death (Gangrene) and amputation (Maryunani, 2013).

Efforts to prevent the spread of diabetic ulcer infection include wound care measures with the appropriate treatment method, which improves the wound healing process. One of the wound treatment methods that can be used, according to AragónSánchez et al. (2012) and Permana et al. (2012), is to keep moisture at the wound's base to prevent bacterial colonization. According to the findings of a study conducted by Permana et al. (2012), wound care media containing honey can improve the healing process of infection-related wounds. Natural honey is one of the replacement therapy media used to treat diabetic foot infection wounds caused by diabetes.

Currently, the treatment of diabetic ulcers is expensive. Hence, other alternative therapies in the form of complementary therapies in the healing of diabetic ulcers are by using other media that are simple, inexpensive, and accessible to the community, one of which is palm sugar. According to the findings of several literature studies, there are similarities in the content of honey, dates, and palm sugar.

One of the components of palm sugar that affects wounds is riboflavin, ascorbic acid (Vitamin C), and water. Riboflavin compounds found in palm sugar can aid in the formation of red blood cells and stimulate the formation of immunoglobulins (Antibodies) produced in bone marrow, thereby improving tissue function. Furthermore, ascorbic acid (Vitamin C) found in palm sugar acts as an antibiotic, weakening and killing bacteria that cause infection in diabetic ulcer wounds, while water media serves as an absorption medium as well as an antiseptic (Heryani, 2016). Researchers used palm sugar as one of the alternative media that can be used in the process of treating diabetic ulcer wounds because Indonesia is one of the largest and best palm sugar producing countries in the Asian region, particularly in Southeast Asia. Furthermore, palm sugar is almost universally available, and the cost is relatively low in the community.

Diabetic ulcer treatment services necessitate a lengthy hospitalization (2-3 weeks), but government policies and regulations implemented through the Social Security Protection Agency (BPJS) health reduce the length of the hospital day to 4-7 days, requiring patients to receive follow-up care at home.

\section{RESEARCH METHOD}

This study used a quasi-research experiment design with one group pre-test and 
post-test designs. All patients with post-hospitalization diabetes mellitus were included in the study. Meanwhile, the study sample consisted of 8 patients who develop diabetic ulcers after hospitalization.The sampling technique employed was criteria-based consecutive sampling which led to:

1. Patients who were willing to participate as respondents.

2. The patient's first post-hospitalization day.

3. Patients diagnosed by doctors as having type 2 diabetes mellitus with complications of grade II and III diabetic ulcers.

4. The patient's blood sugar levels were under control and close to the normal value limit, with the current blood sugar level value (GDS) greater than $50 \mathrm{mg} / \mathrm{dl}$ and less than $200 \mathrm{mg} / \mathrm{dl}$ prior to palm sugar wound treatment.

5. Diabetic ulcer patients with a degree 2-3 classification at stages A-D (based on the University of Texas ulcer classification).

6. Post-acute care patients at Dr. Slamet Garut in 2021

The research instrument deployed diabetic ulcer treatment standard operating procedures (SOPs) and a Leg Ulcer Measurement Tool (LUMT) observation sheet. The mean score of diabetic ulcus characteristics before and after action was used in univariate analysis. The analysis was based on the data normality test results. Bivariate analysis employed a dependent t-test based on the results of the one KS and Shapiro-Wilk tests for data normality.

\section{RESULT AND DISCUSSION}

According to the characteristics of the respondents, the majority of the respondents (55.6 percent) were male. Almost all of the respondents ( 88.9 percent) had a history of smoking and almost all of the respondents ( 88.9 percent) were elderly (56->65 years). Most of the respondents (66.7 percent) had type 2 diabetes mellitus less than 2 years and 55.6 percent had diabetic ulcer less than 6 months, and the majority of the respondents (66.7 percent) had grade II diabetic ulcers.

Wounds were treated with palm sugar media once a day for two weeks, followed by a post test on the fourteenth day, which involved assessing wounds again using LUMT observation sheets.

Table 1 provides an overview of wound care with sugar aren pre-action and postaction:

\begin{tabular}{cccrr}
\hline Diabetic Ulcer & \multicolumn{2}{c}{ Mean } & Std. Deviation Minimal & \multicolumn{2}{c}{ Maximal } \\
\hline Pre- Care & 38.56 & 5.855 & 31 & 46 \\
Post- Care & 19.89 & 4.833 & 15 & 29 \\
\hline
\end{tabular}

The following table 2 shows the results of the analysis on the effectiveness of wound care with palm sugar media against the process of repairing pre-care diabetic ulcers and post-care in Type 2 DM patients:

Table 2 The Effect of Palm Sugar Wound Care on Diabetic Ulcer Repair Before and After Surgery in Type 2 Diabetes Patients

\begin{tabular}{lllllll}
\hline \multicolumn{6}{c}{ Different Values on Pre-care and Post-care Pairs } \\
\hline \multicolumn{7}{c}{$95 \%$ Confidence } \\
$\begin{array}{l}\text { Pre-Post } \\
\text { Care }\end{array}$ & Mean & SD & $\begin{array}{l}\text { Interval of the } \\
\text { Difference } \\
\text { Lower }\end{array}$ Upper & $P_{\text {value }}$ \\
& 18,667 & 5,074 & 14,766 & 22,567 & 11,036 & 0,000 \\
\hline
\end{tabular}


According to table 2, the average diabetic ulcer post-wound treatment action with palm sugar is 18,667 with a standard deviation of 5,074. Based on a confidence interval of 95 percent greater than one, it can be concluded that wound treatment with palm sugar media is effective in the process of repairing diabetic ulcers. The results of statistical tests using the t-test dependent test yielded a value of $\mathrm{P}=0.000$, implying that wound treatment with palm sugar media was effective against the process of repairing diabetic ulcers in patients with type 2 diabetes mellitus.

In diabetic ulcer patients, wound care is a critical step in preventing infection and complications. The basic principle of diabetic ulcer treatment is to create a moist wound healing environment or to keep the wound moist at all times (ADA, 2013). In addition to preserving moisture, dressings should take into account the size, depth, and location of ulcers (Clayton, Warren, Jr. \& Elasy, T.A., 2009). In this case, the researchers used palm sugar to treat wounds. Palm sugar contains several macro and micronutrient elements, with palm sugar having a higher content of both than white sugar. Thiamine (Vitamin B1), Riboflavin (Vitamin B2), Nicotinic Acid (Vitamin B3), Pyridoxine (Vitamin B6), Cyanocobalamin (Vitamin B12), Ascorbic Acid (Vitamin C), protein, and mineral salts are among the micronutrients found in palm sugar. Palm sugar contains vitamin $\mathrm{C}$, an antioxidant that promotes skin health and protects against skin damage. Riboflavin, which aids in the formation of red blood cells, produces antibodies, as do enzymes, which produce the energy required by the human body, vitamin A, which improves the tissue working system, and the substance Ascorbic Acid, which has antibiotic properties (Heryani, 2016).

The researchers determined the intervention time for two weeks, based on the wound healing phase theory, in which the fourth to the twenty-first day is the proliferation phase (Bryant, R \& Nix, D., 2007). During this phase of proliferation, vascular integrity improves, the incision basin is filled with connective tissue, and the wound surface is coated with a new epithelium. This phase is marked by epitheliization, neoangigenesis, and matrix deposition/collagen synthesis. The study used a LUMT observation sheet before administering the first and 14th day (post-test) observation sheets to determine the characteristics of diabetic ulcers before and after wound treatment with palm sugar media $1 \mathrm{x}$ per day for 2 weeks. The results showed that the average number of post-treatment diabetic ulcers with palm sugar in type $2 \mathrm{DM}$ patients was 19.89 (LUMT assessment 0-68), while the average number of post-action diabetic ulcers was relatively low.

\section{CONCLUSION}

Based on the study's findings, it is concluded that wound treatment with palm sugar media is effective in the process of repairing diabetic ulcers. The wound treatment with palm sugar media can be developed and used to treat diabetic ulcer wounds as one of the wound treatment media with topical complementary therapies.

\section{REFERENCES}

American Diabetes Association. (2013). Standards of Medical Care in Diabetes-2013. Diabetes Journal. 36(1):S11-S50

Aragón-Sánchez, J., Lázaro-Martínez, J. L., Pulido-Duque, J., \& Maynar, M. (2012). From the diabetic foot ulcer and beyond: How do foot infections spread in patients with diabetes? Diabetic Foot and Ankle, 3, 1-7. https://doi.org/10.3402/dfa.v3i0.18693 
Bryant, R \& Nix, D. (2007). Acute and Chronic Wound Current Management Concept. 3th Edition. St. Louis: Mosby Elsevier

Christia, S., Yuwono, A., \& Fakhrurrazy. (2015). Kejadian Neuropati Vaskulopati Pada Pasien Ulkus Diabetik di Poliklinik Kaki Diabetik. Berkala Kedokteran,11(1), $25-32$.

Clayton, Warren,Jr. \& Elasy, T.A. (2009). A review Of The Pathophysiology, Classification, And Treatment Of Foot Ulcers In Diabetic Petient. Cilinical Diabetic. 27(2):52-58.

Heryani, H. (2016). Palm Sugar Priorities \& Product Development Strategy. Lambung Mangkurat Univercity Press.

Maryunani, A. (2013). 2013. Modern wound care (Modern Woundcare). Jakarta; Trans Info Medika.

Permana, R. E., Suryani, M., \& Supriyono, M. (2012). Effectiveness of Natural Honey Treatment Against Wound Healing diabetic foot infections (IKD) (Case Study at Bangetayu Health Center and Semarang Genuk Health Center). 005(February), 1-6. 